\title{
Index to Volume 48
}

A

\section{ACADEMIC LIBRARIES}

Applegate, Rachel. Whose Decline? Which Academic Libraries Are "Deserted" in Terms of Reference Transactions?, 48(2):176-189

Cahoy, Ellysa Stern, and Loanne Snavely. Maximizing Local and National Assessment for Evidence-Based Librarianship, 48(3):216

Elliott, Julie. Barriers to Extracurricular Reading Promotion in Academic Libraries, 48(4):340-346

Fuller, Kate, Jill Livingston, Stephanie Willen Brown, Susanna Cowan, Thomas Wood, and Leslie Porter. Making Unmediated Access to E-Resources a Reality: Creating a Usable ERM Interface, 48(3):287301

Granfield, Diane, and Mark Robertson. Preference for Reference: New Options and Choices for Academic Library Users, 48(1):44-53

Hartman, Karen A. Retaining Intellectual Capital: Retired Faculty and Academic Libraries, 48(4):420

Lewis, Leslie A. From the Front Lines: An Academic Librarian Reports on the Impact of APA's New Electronic Reference Guidelines, 48(2):128

Meserve, Harry C., Sandra E. Belanger, Joan Bowlby, and Lisa Rosenblum. Developing a Model for Reference Research Statistics: Applying the "Warner Model" of Reference Question Classification to Streamline Research Services, 48(3):247-258

Shumaker, David. Who Let the Librarians Out? Embedded Librarianship and the Library Manager, 48(3):239-242

Sobel, Karen. Promoting Library Reference Services to First-Year Undergraduate Students: What Works?, 48(4):362-371

Stein, Merrill, Teresa Edge, John M. Kelley, Dane Hewlett, and James F. Trainer. Using Continuous Quality Improvement Methods to Evaluate Library Service Points, 48(1):78-85

Walsh, Tiffany R., and Christopher V. Hollister. Creating a Digital Archive for Students' Research in a Credit
Library Course, 48(4):391-400

Accidental Technologist (column)

From Accidental Technologist to Accidental Traveler, or What I Learned from a Month in Shanghai, 48(2):118-121

Teaching Reference: Ten Questions from a First Attempt, 48(4):330-333

Adams, Tina M. See Portree, Martha ADULT SERVICES

Hermes, Virginia, Mary Anne Hile, and Johnetta L. Frisbie. Reviving Literary Discussion: Book Club to Go Kits, 48(1):30-34

The Alert Collector (column)

Brush, Denise A. Global Warming: Resources to Sustain a Collection, 48(4):334-339

Burcher, Charlotte, Neil Hollands, Andrew Smith, Barry Trott, and Jessica Zellers. Core Collections in Genre Studies: Fantasy Fiction 101, 48(3):226-231

Monroe, Amalia L. American Presidential Power: A Research Guide, 48(2):122127

Stoddart, Richard A., Brett Spencer, and Adrienne R. McPhaul. A Select Survey of Criminal Justice Administration and Criminology Resources for Research, Reference, and Collection Development, 48(1):13-19

The Ambidextrous Librarian, or "You Can Teach a Middle-Aged Dog Some New Tricks!", 48(1):26-28

American Presidential Power: A Research Guide, 48(2):122-127

AMERICAN PSYCHOLOGICAL ASSOCIATION (APA)

Lewis, Leslie A. From the Front Lines: An Academic Librarian Reports on the Impact of APA's New Electronic Reference Guidelines, 48(2):128-131

Antell, Karen, and Jie Huang

Subject Searching Success: Transaction Logs, Patron Perceptions, and Implications for Library Instruction, 48(1):68-76

Antell, Karen, ed.

Professional Materials, 48(1):100-101, 48(2):205-208, 48(3):315-319, 48(4):414-417

Applegate, Rachel

Whose Decline? Which Academic
Libraries Are "Deserted" in Terms of Reference Transactions?, 48(2):176189

\section{B}

Banks, Julie, and Carl Pracht Reference Desk Staffing Trends: A Survey, 48(1):54-59

Barriers to Extracurricular Reading Promotion in Academic Libraries, 48(4):340-346

Belanger, Sandra E. See Meserve, Harry C. Best Free Reference Websites, 48(1):3540

Best Historical Materials, 48(1):41-43 BIBLIOGRAPHIC INSTRUCTION

Antell, Karen, and Jie Huang. Subject Searching Success: Transaction Logs, Patron Perceptions, and Implications for Library Instruction, 48(1):68-76

Robertson, Michael J., and James G. Jones. Exploring Academic Library Users' Preferences of Delivery Methods for Library Instruction: Webpage, Digital Game, and Other Modalities, 48(3):259-269

Walsh, Tiffany R., and Christopher V. Hollister. Creating a Digital Archive for Students' Research in a Credit Library Course, 48(4):391-400

BLACK FEMINIST LITERATURE

Hankins, Rebecca. Uncovering Black Feminist Writers 1963-90: An Evaluation of Their Coverage in Research Tools, 48(3):270-286

BOOK DISCUSSION GROUPS

Hermes, Virginia, Mary Anne Hile, and Johnetta L. Frisbie. Reviving Literary Discussion: Book Club to Go Kits, 48(1):30-34

Bowlby, Joan. See Meserve, Harry C. Brier, David J., and Vickery Kaye Lebbin. Perception and Use of PowerPoint at Library Instruction Conferences, 48(4):352-361

Brown, Stephanie Willen. See Fuller, Kate Brush, Denise A

Global Warming: Resources to Sustain a Collection, 48(4):334-339

Building on a Firm Foundation: Readers' Advisory over the Next Twenty-Five Years, 48(2):132-135

Burcher, Charlotte, Neil Hollands, 
Andrew Smith, Barry Trott, and Jessica Zellers

Core Collections in Genre Studies:

Fantasy Fiction 101, 48(3):226-231

Burke, Susan K.

Use of Public Libraries by Immigrants, 48(2):164-174

BUSINESS REFERENCE SOURCES

BRASS Business Reference Sources Committee. Outstanding Business References Sources, 48(2):136-140

Gonzalez, Adriana Trujillo, Vincci Kwong, Julie Strange, and Julie Yen. A Guide to Excellent Creative Business Libraries and Business Centers, 48(3):232-238

"But I Want a Real Book"

Erratum, 48(1): 10

\section{C}

Cahoy, Ellysa Stern, and Loanne Snavely Maximizing Local and National Assessment for Evidence-Based Librarianship, 48(3):216, 218-223

COLLECTION DEVELOPMENT

Stoddart, Richard A., Brett Spencer, and Adrienne R. McPhaul. A Select Survey of Criminal Justice Administration and Criminology Resources for Research, Reference, and Collection Development, 48(1):13-19

Core Collections in Genre Studies: Fantasy Fiction 101, 48(3):226-231

Cowan, Susan. See Fuller, Kate

Creating a Digital Archive for Students' Research in a Credit Library Course, 48(4):391-400

\section{CUSTOMER SERVICE}

Vilelle, Luke, and Christopher C. Peters. Don't Shelve the Questions: Defining Good Customer Service for Shelvers, 48(1):60-67

\section{D}

\section{DATABASES}

Fuller, Kate, Jill Livingston, Stephanie Willen Brown, Susanna Cowan, Thomas Wood, and Leslie Porter. Making Unmediated Access to E-Resources a Reality: Creating a Usable ERM Interface, 48(3):287301

Developing a Model for Reference Research Statistics: Applying the "Warner Model" of Reference Question Classification to Streamline Research Services, 48(3):247-258

DIGITAL REFERENCE SERVICES. See VIRTUAL REFERENCE SERVICES

DISTANCE EDUCATION

Kern, M. Kathleen. Teaching Reference: Ten Questions from a First Attempt, 48(4):330-333

Doherty, John J. See Portree, Martha Don't Shelve the Questions: Defining
Good Customer Service for Shelvers, 48(1):60-67

\section{E}

Edge, Teresa. See Stein, Merrill

ELECTRONIC RESOURCES

Fuller, Kate, Jill Livingston, Stephanie Willen Brown, Susanna Cowan, Thomas Wood, and Leslie Porter. Making Unmediated Access to E-Resources a Reality: Creating a Usable ERM Interface, 48(3):287301

Elliott, Julie

Barriers to Extracurricular Reading Promotion in Academic Libraries, 48(4):340-346

Evans, R. Sean. See Portree, Martha Exploring Academic Library Users' Preferences of Delivery Methods for Library Instruction: Webpage, Digital Game, and Other Modalities, 48(3):259-269

Fagerstrom, David obituary, 48(4):414

FANTASY FICTION

Burcher, Charlotte, Neil Hollands, Andrew Smith, Barry Trott, and Jessica Zellers. Core Collections in Genre Studies: Fantasy Fiction 101, 48(3):226-231

The Flow State: An Interview with RUSA's Section Chairs, 48(3):224-225

Fontenot, Mitchell J. The Ambidextrous Librarian, or "You Can Teach a Middle-Aged Dog Some New Tricks!", 48(1):26-28

For Your Enrichment (column) Gonzalez, Adriana Trujillo, Vincci Kwong, Julie Strange, and Julie Yen. A Guide to Excellent Creative Business Libraries and Business Centers, 48(3):232-238

Knibbe-Haanstra, Marcella. Reference Desk Dilemmas: The Impact of New Demands on Librarianship, 48(1):20, 22-25

Lewis, Leslie A. From the Front Lines: An Academic Librarian Reports on the Impact of APA's New Electronic Reference Guidelines, 48(2):128131, 129-131

Frisbie, Johnetta L. See Hermes, Virginia

From Accidental Technologist to Accidental Traveler, or What I Learned from a Month in Shanghai, 48(2):118121

From Committees of RUSA

BRASS Business Reference Sources Committee. Outstanding Business References Sources, 48(2):136-140 Interlibrary Loan Committee. Interlibrary Loan Code for the United States,

INDEX TO VOLUME 48

48(4):418-419

Notable Books, 48(4):347-348

RUSA CODES Reading List Council. The Reading List, 48(4):350-351

RUSA CODES Reference Sources Committee. Outstanding Reference Titles, 48(4):349

RUSA History Section. Best Historical Materials, 48(1):41-43

From the Editor (column)

Cahoy, Ellysa Stern, and Loanne Snavely. Maximizing Local and National Assessment for Evidence-Based Librarianship, 48(3):216, 218-223

Kudos Redux, 48(4):324, 326, 329

Radford, Marie L. A Personal Choice: Reference Service Excellence, 48(2): 108, 110-115

Kieft, Robert H. The Return of the Guide to Reference (Books), 48(1):4, 6, 8-10

From the Front Lines: An Academic Librarian Reports on the Impact of APA's New Electronic Reference Guidelines, 48(2):128-131

From the President of RUSA (column)

The Flow State: An Interview with RUSA's Section Chairs, 48(3):224-225

A History of Innovation and a Future of Possibility, 48(2):116-117

Visions of RUSA Future, 48(4):327-329

Welcome to the Table, 48(1):12, 19

Fuller, Kate, Jill Livingston, Stephanie Willen Brown, Susanna Cowan, Thomas Wood, and Leslie Porter Making Unmediated Access to E-Resources a Reality: Creating a Usable ERM Interface, 48(3):287301

\section{G}

Global Warming: Resources to Sustain a Collection, 48(4):334-339

Gonzalez, Adriana Trujillo, Vincci Kwong, Julie Strange, and Julie Yen A Guide to Excellent Creative Business Libraries and Business Centers, 48(3):232-238

Granfield, Diane, and Mark Robertson

Preference for Reference: New Options and Choices for Academic Library Users, 48(1):44-53

Gregory, Cynthia L.

But I Want a Real Book, Erratum, 48(1): 10

A Guide to Excellent Creative Business Libraries and Business Centers, 48(3):232-238

\section{GUIDELINES}

Guidelines for Library and Information Services to Older Adults, 48(2):209212

Interlibrary Loan Code for the United States, 48(4):418-419

Interlibrary Loan Committee. Interlibrary Loan Code for the United States, 48(4):418-419 


\section{INDEX TO VOLUME 48}

Hankins, Rebecca

Uncovering Black Feminist Writers 196390: An Evaluation of Their Coverage in Research Tools, 48(3):270-286

Hartman, Karen A.

Retaining Intellectual Capital: Retired Faculty and Academic Libraries, 48(4):420

Henry, Deborah B. See Neville, Tina M. Hermes, Virginia, Mary Anne Hile, and Johnetta L. Frisbie Reviving Literary Discussion: Book Club to Go Kits, 48(1):30-34

Hewlett, Dane. See Stein, Merrill Hile, Mary Anne. See Hermes, Virginia A History of Innovation and a Future of Possibility, 48(2):116-117

Hollands, Neil. See Burcher, Charlotte Hollister, Christopher V. See Walsh, Tiffany R.

Huang, Jie. See Antell, Karen

\section{IMMIGRANTS}

Burke, Susan K. Use of Public Libraries by Immigrants, 48(2):164-174

INFORMATION LITERACY

Walsh, Tiffany R., and Christopher V. Hollister. Creating a Digital Archive for Students' Research in a Credit Library Course, 48(4):391-400

Instructions to Authors, 48(1):102-104 INTERLIBRARY LOAN

Interlibrary Loan Committee. Interlibrary Loan Code for the United States, 48(4):418-419

\section{J}

Johnson, Corey M. See Nicol, Erica A. Jones, James G. See Robertson, Michael J.

Kelley, John M. See Stein, Merrill Kern, M. Kathleen

Teaching Reference: Ten Questions from a First Attempt, 48(4):330-333

Kern, M. Kathleen.

From Accidental Technologist to Accidental Traveler, or What I Learned from a Month in Shanghai, 48(2):118-121

Kieft, Robert H.

The Return of the Guide to Reference (Books), 48 (1), 4, 6, 8-10.

Knibbe-Haanstra, Marcella

Reference Desk Dilemmas: The Impact of New Demands on Librarianship, 48(1):20,22-25

Kwong, Vincci. See Gonzalez, Adriana Trujillo

Lebbin, Vickery Kaye. See Brier, David J. Lewis, Leslie A.
From the Front Lines: An Academic Librarian Reports on the Impact of APA's New Electronic Reference Guidelines, 48(2):128-131

\section{LIBRARY INSTRUCTION}

PRESENTATIONS

Brier, David J., and Vickery Kaye Lebbin. Perception and Use of PowerPoint at Library Instruction Conferences, 48(4):352-361

LIBRARY SCIENCE EDUCATION

Kern, M. Kathleen. Teaching Reference: Ten Questions from a First Attempt, 48(4):330-333

Library Services to an Aging Population Committee

Guidelines for Library and Information Services to Older Adults, 48(2):209_ 212

Livingston, Jill. See Fuller, Kate

\section{M}

Management (column)

Fontenot, Mitchell J. The Ambidextrous Librarian, or "You Can Teach a Middle-Aged Dog Some New Tricks!", 48(1):26-28

Shumaker, David. Who Let the Librarians Out? Embedded Librarianship and the Library Manager, 48(3):239-242

McPhaul, Adrienne R. See Stoddart, Richard A.

Meserve, Harry C., Sandra E. Belanger, Joan Bowlby, and Lisa Rosenblum Developing a Model for Reference Research Statistics: Applying the "Warner Model" of Reference Question Classification to Streamline Research Services, 48(3):247-258

\section{MICROSOFT POWERPOINT}

Brier, David J., and Vickery Kaye Lebbin. Perception and Use of PowerPoint at Library Instruction Conferences, 48(4):352-361

Monroe, Amalia L.

American Presidential Power: A Research Guide, 48(2): 122-127

\section{N}

Neville, Tina M., and Deborah B. Henry Reference Classification-Is It Time to Make Some Changes? 48(4):372-383

Nicol, Erica A., and Corey M. Johnson Volunteers in Libraries: Program Structure, Evaluation, and Theoretical Analysis, 48(2):154-163

Nixon, Judith M., ed.

Management (column), 48(1):26-28, 48(3):239-242

Notable Books, 48(4):347-348

\section{0}

\section{OLDER ADULTS}

Library Services to an Aging Population Committee. Guidelines for Library and Information Services to Older
Adults, 48(2):209-212

ONLINE EDUCATION. See DISTANCE EDUCATION

ONLINE PUBLIC ACCESS CATALOGS

Antell, Karen, and Jie Huang. Subject Searching Success: Transaction Logs, Patron Perceptions, and Implications for Library Instruction, 48(1):68-76

Outstanding Business References Sources, 48(2):136-140

Outstanding Reference Titles, 48(4):349

Overcoming Transactional Distance: Instructional Intent in an E-mail Reference Service, 48(2):142-152

\section{P}

Perception and Use of PowerPoint at Library Instruction Conferences, 48(4):352-361

Peters, Christopher C. See Vitelle, Luke Porter, Leslie. See Fuller, Kate

Portree, Martha, R. Sean Evans, Tina M. Adams, and John J. Doherty

Overcoming Transactional Distance: Instructional Intent in an E-mail Reference Service, 48(2):142-152

\section{POWERPOINT}

Brier, David J., and Vickery Kaye Lebbin. Perception and Use of PowerPoint at Library Instruction Conferences, 48(4):352-361

Pracht, Carl. See Banks, Julie

Preference for Reference: New Options and Choices for Academic Library Users, 48(1):44-53

PRESENTATIONS

Brier, David J., and Vickery Kaye Lebbin. Perception and Use of PowerPoint at Library Instruction Conferences, 48(4):352-361

Promoting Library Reference Services to First-Year Undergraduate Students: What Works?, 48(4):362-371

PUBLIC LIBRARIES

Burke, Susan K. Use of Public Libraries by Immigrants, 48(2):164-174

Meserve, Harry C., Sandra E. Belanger, Joan Bowlby, and Lisa Rosenblum. Developing a Model for Reference Research Statistics: Applying the "Warner Model" of Reference Question Classification to Streamline Research Services, 48(3):247-258

\section{QUALITY IMPROVEMENT}

Stein, Merrill, Teresa Edge, John M. Kelley, Dane Hewlett, and James F. Trainer. Using Continuous Quality Improvement Methods to Evaluate Library Service Points, 48(1):78-85

\section{$\mathbf{R}$}

Radcliff, Carolyn J., ed.

Reference Books, 48(1):87-100, 48(2):191-205, 48(3):303-315, 
48(4):402-414

Radford, Marie L.

A Personal Choice: Reference Service Excellence, 48(2):108, 110-115

Readers' Advisory (column)

Elliott, Julie. Barriers to Extracurricular Reading Promotion in Academic Libraries, 48(4):340-346

Hermes, Virginia, Mary Anne Hile, and Johnetta Frisbie. Reviving Literary Discussion: Book Club to Go Kits, 48(1):30-34

Stover, Kaite Mediatore. Stalking the Wild Appeal Factor: Readers' Advisory and Social Networking Sites, 48(3):243-246, 269

Trott, Barry. Building on a Firm Foundation: Readers' Advisory over the Next Twenty-Five Years, 48(2):132-135

The Reading List 2009, 48(4):350-351

Reference Classification-Is It Time to Make Some Changes?, 48(4):372-383

Reference Desk Dilemmas: The Impact of New Demands on Librarianship, 48(1):20, 22-25

Reference Desk Staffing Trends: A Survey, 48(1):54-59

\section{REFERENCE SERVICES}

Applegate, Rachel. Whose Decline? Which Academic Libraries Are "Deserted" in Terms of Reference Transactions?, 48(2):176-189

Banks, Julie, and Carl Pracht. Reference Desk Staffing Trends: A Survey, 48(1):54-59

Fontenot, Mitchell J. The Ambidextrous Librarian, or "You Can Teach a Middle-Aged Dog Some New Tricks!", 48(1):26-28

Fuller, Kate, Jill Livingston, Stephanie Willen Brown, Susanna Cowan, Thomas Wood, and Leslie Porter. Making Unmediated Access to E-Resources a Reality: Creating a Usable ERM Interface, 48(3):287301

Granfield, Diane, and Mark Robertson. Preference for Reference: New Options and Choices for Academic Library Users, 48(1):44-53

Knibbe-Haanstra, Marcella. Reference Desk Dilemmas: The Impact of New Demands on Librarianship, 48(1):20, 22-25

Lewis, Leslie A. From the Front Lines: An Academic Librarian Reports on the Impact of APA's New Electronic Reference Guidelines, 48(2): 128

Meserve, Harry C., Sandra E. Belanger, Joan Bowlby, and Lisa Rosenblum. Developing a Model for Reference Research Statistics: Applying the "Warner Model" of Reference Question Classification to Streamline Research Services, 48(3):247-258
Radford, Marie L. A Personal Choice: Reference Service Excellence, 48(2):108, 110-115

Sobel, Karen. Promoting Library Reference Services to First-Year Undergraduate Students: What Works?, 48(4):362-371

REFERENCE SOURCES

RUSA CODES Reference Sources Committee. Outstanding Reference Titles, 48(4):349

REFERENCE STATISTICS

Neville, Tina M., and Deborah B. Henry. Reference Classification-Is It Time to Make Some Changes?, 48(4):372383

Retaining Intellectual Capital: Retired Faculty and Academic Libraries, 48(4):384-390

The Return of the Guide to Reference (Books), 48(1):4, 6, 8-10

Reviving Literary Discussion: Book Club to Go Kits, 48(1):30-34

Robertson, Mark. See Granfield, Diane

Robertson, Michael J., and James G. Jones Exploring Academic Library Users' Preferences of Delivery Methods for Library Instruction: Webpage, Digital Game, and Other Modalities, 48(3):259-269

Rosenblum, Lisa. See Meserve, Harry C. RUSA

BRASS Business Reference Sources Committee. Outstanding Business References Sources, 48(2):136-140

Interlibrary Loan Committee. Interlibrary Loan Code for the United States, 48(4):418-419

Library Services to an Aging Population Committee. Guidelines for Library and Information Services to Older Adults, 48(2):209-212

RUSA CODES Reading List Council. The Reading List, 48(4):350-351

RUSA CODES Reference Sources Committee. Outstanding Reference Titles, 48(4):349

RUSA History Section. Best Historical Materials, 48(1):41-43

RUSA Machine-Assisted Reference Section. Best Free Reference Websites, 48(1):35-40

RUSA Notable Books Council. Notable Books, 48(4):347-348

Visions of RUSA Future, 48(4):327-329

Wyatt, Neal. The Flow State: An Interview with RUSA's Section Chairs, 48(3):224-225

\section{$\mathbf{S}$}

A Select Survey of Criminal Justice Administration and Criminology Resources for Research, Reference, and Collection Development, 48(1):13-19

SHELVERS
Vilelle, Luke, and Christopher C. Peters. Don't Shelve the Questions: Defining Good Customer Service for Shelvers, 48(1):60-67

Shumaker, David

Who Let the Librarians Out? Embedded Librarianship and the Library Manager, 48(3):239-242

Smith, Andrew. See Burcher, Charlotte

Snaveley, Loanne. See Cahoy, Ellysa Stern Sobel, Karen

Promoting Library Reference Services to First-Year Undergraduate Students: What Works?, 48(4):362-371

Spencer, Brett. See Stoddart, Richard A. Stalking the Wild Appeal Factor: Readers' Advisory and Social Networking Sites, 48(3):269

Stein, Merrill, Teresa Edge, John M. Kelley, Dane Hewlett, and James F. Trainer

Using Continuous Quality Improvement Methods to Evaluate Library Service Points, 48(1):78-85

Stoddart, Richard A., Brett Spencer, and Adrienne R. McPhaul

A Select Survey of Criminal Justice Administration and Criminology Resources for Research, Reference, and Collection Development, 48(1):13-19

Stover, Kaite Mediatore

Stalking the Wild Appeal Factor: Readers' Advisory and Social Networking Sites, 48(3):269

Strange, Julie. See Gonzalez, Adriana Trujillo

Subject Searching Success: Transaction Logs, Patron Perceptions, and Implications for Library Instruction, 48(1):68-76

SURVEYS

Cahoy, Ellysa Stern, and Loanne Snavely. Maximizing Local and National Assessment for Evidence-Based Librarianship, 48(3):218-223

\section{T}

Teaching Reference: Ten Questions from a First Attempt, 48(4):330-333

Trainer, James F. See Stein, Merrill

Trott, Barry. See Burcher, Charlotte

Trott, Barry, ed.

Readers' Advisory, 48(1):30-34, 48(2):132-135, 48(3):243-246, 48(4):340-346

Trujillo, Adriana. See Gonzalez, Adriana Trujillo

U

Uncovering Black Feminist Writers 196390: An Evaluation of Their Coverage in Research Tools, 48(3):270-286

Use of Public Libraries by Immigrants, 48(2):164-174 


\section{INDEX TO VOLUME 48}

Using Continuous Quality Improvement Methods to Evaluate Library Service Points, 48(1):78-85

\section{V}

Vilelle, Luke, and Christopher C. Peters Don't Shelve the Questions: Defining Good Customer Service for Shelvers, 48(1):60-67

VIRTUAL REFERENCE SERVICES

Portree, Martha, R. Sean Evans, Tina M. Adams, and John J. Doherty. Overcoming Transactional Distance: Instructional Intent in an E-mail Reference Service, 48(2):142-152

Visions of RUSA Future

Wyatt, Neal, 48(4):327-329

Volunteers in Libraries: Program Structure, Evaluation, and Theoretical Analysis, 48(2):154-163

\section{W}

Walsh, Tiffany R., and Christopher V. Hollister

Creating a Digital Archive for Students' Research in a Credit Library Course, 48(4):391-400

WEB RESOURCES

Best Free Reference Websites, 48(1):3540

Welcome to the Table, 48(1):19

Who Let the Librarians Out? Embedded Librarianship and the Library Manager, 48(3):239-242

Whose Decline? Which Academic Libraries Are "Deserted" in Terms of Reference Transactions?, 48(2):176189

Wood, Thomas. See Fuller, Kate

Wyatt, Neal

The Flow State: An Interview with RUSA's Section Chairs, 48(3):224-225

A History of Innovation and a Future of Possibility, 48(2):116-117

Visions of RUSA Future, 48(4):327-329

Welcome to the Table, 48(1):12, 19

Wyatt, Neal, ed.

The Alert Collector (column), 48(1):13$19,48(2): 122-127,48(3): 226-231$, 48(4):334-339

\section{Y}

Yen, Julie. See Gonzalez, Adriana Trujillo

Zabel, Diane

From the Editor, 48(1):4, 6, 8-10, 48(2):108, 110-115, 48(3):216, 218-223, 48(4):324, 326, 329

Zabel, Diane, ed.

For Your Enrichment (column), 48(1):20, 22-25, 48(2):128-131, 48(3):232-238

Zellers, Jessica. See Burcher, Charlotte

\section{SOURCES}

A

Africa and the Americas: Culture, Politics, and History, 48(4):402

America in Revolt During the 1960s and 1970s, 48(2):191

American Civil War, 48(3):303-304

American Heroes, 48(3):303-304

American Villains, 48(3):303-304

Annual Review of Global Peace Operations, 2008, 48(2):191-192

Answering Consumer Health Questions: The Medical Library Association Guide for Reference Librarians, 48(3):315

Answers to the Health Questions People Ask in Libraries, 48(4):414-415

Berkshire Encyclopedia of Extreme Sports, 48(1):87

Blood on the Stage: Milestone Plays of Crime, Mystery, and Detection: An Annotated Repertoire, 1900-1925, 48(3):304

Books and Beyond: The Greenwood Encyclopedia of New American Reading, 48(4):415

British Film Noir Guide, 48(1):87-88

\section{C}

Career Opportunities in the Internet, Video Games, and Multimedia, 48(1):88

Chronology of American History, 48(4):402-403

Climate Change: In Context, 48(3):304

College Financing Information for Teens, 48(2): 192

Conflict between India and Pakistan: An Encyclopedia, 48(4):403

Crash Course in Reference, 48(3):315

Crime \& Punishment in the U. S., 48(3):305

Cultural Encyclopedia of the Body, 48(4):403-404

\section{D}

Daily Life in the New Testament, 48(2):192-193

Debt Information for Teens, 48(1):88-89

Disasters, Accidents, and Crises in American History: A Reference Guide to the Nation's Most Catastrophic Events, 48(2): 193

Diseases and Disorders, 48(4):404-405

The Drama 100: A Ranking of the Greatest Plays of All-Time, 48(1):89

\section{E}

The Eighties in America, 48(2):193-194 Encyclopedia of African-American Literature, 48(2):194-195

Encyclopedia of the African Diaspora:
Origins, Experiences, and Culture, 48(3):308-309

Encyclopedia of American Government and Civics, 48(4):405

The Encyclopedia of the Arab-Israeli Conflict: A Political, Social, and Military History, 48(2):197-198

Encyclopedia of Bilingual Education, 48(3):305-306

The Encyclopedia of Civil War Medicine, 48(3):306

Encyclopedia of Counseling, 48(4):405406

Encyclopedia of Educational Psychology, 48(2):195

Encyclopedia of Epidemiology, 48(1):8990

Encyclopedia of Gay and Lesbian Popular Culture, 48(1):90

Encyclopedia of Geographic information Science, 48(1):90-91

Encyclopedia of Global Health, 48(1):91

Encyclopedia of Global Warming and Climate Change, 48(2):195-196

Encyclopedia of Hispanic-American Literature, 48(4):406

Encyclopedia of Interpersonal Violence, 48(3):306-307

Encyclopedia of the Jazz Age: From the End of World War I to the Great Crash, 48(2): 198

Encyclopedia of the Jewish Diaspora: Origins, Experiences and Culture, 48(4):407-408

Encyclopedia of Love in World Religions, 48(1):91-92

Encyclopedia of New Year's Holidays Worldwide, 48(3):307

The Encyclopedia of North American Colonial Conflicts to 1775: A Political, Social, and Military History, 48(4):406-407

Encyclopedia of Obesity, 48(1):92

Encyclopedia of Political Communication, 48(2): 196

Encyclopedia of Psychology and Law, 48(1):93

Encyclopedia of Race, Ethnicity, and Society, 48(2): 196-197

Encyclopedia of Race and Racism, 48(1):93-94

Encyclopedia of Scientific Principles, Laws, and Theories, 48(3):307-308

Encyclopedia of the Social and Cultural Foundations of Education, 48(4):408409

Encyclopedia of Social Problems, 48(3):308

Encyclopedia of Society and Culture in the Ancient World, 48(1):94

Encyclopedia of Society and Culture in the Medieval World, 48(4):407

Encyclopedia of Stem Cell Research, 48(4):407

Encyclopedia of World History, 48(4):409

Encyclopedia of World's Fairs and 
Expositions, 48(3):309-310

Everyday Finance: Economics, Personal Money Management, and Entrepreneurship, 48(3):310

\section{F}

Foyle's Philavery: A Treasury of Unusual Words, 48(2):198-199

\section{G}

The Gale Encyclopedia of Diets: A Guide to Health and Nutrition, 48(2):199

Gamers in the Library?! The Why, What, and How of Video Game Tournaments for All Ages, 48(2):205

A Good Match: Library Career Opportunities for Graduates of Liberal Arts Colleges, 48(1):100

Gotcha Good! Nonfiction Books to Get Kids Excited About Reading, 48(3):315-316

The Greenwood Encyclopedia of Folktales and Fairy Tales, 48(1):94-95

The Greenwood Encyclopedia of Latino Literature, 48(4):409-410

\section{H}

Handbook to Life in the Medieval World, 48(2): 199-200

The Handy 5, 48(2):205-206

The Harlem Renaissance, 48(3):310-311

The Holiness-Pentecostal Movement: A Comprehensive Guide, 48(3):311

Holocaust Literature, 48(2):200

\section{I}

Icons of R\&B and Soul: An Encyclopedia of the Artists Who Revolutionized Rhythm, 48(1):95

Icons of Rock: An Encyclopedia of The Legends Who Changed Music forever, 48(1):95

The Illustrated Guide to the Bible, 48(1):95-96

Information Literacy Meets Library 2.0, 48(4):415-416

International Encyclopedia of Organization Studies, 48(2):200-201

Is Consulting for You? A Primer for Information Professionals, 48(1):100101

\section{$\mathbf{L}$}

The Legislative Branch of the Federal Government: People, Process, and Politics, 48(4):410

Let's Talk Turkey: The Stories Behind America's Favorite Expressions, 48(3):311-312

Library 2.0 and Beyond: Innovative Technologies and Tomorrow's User,
48(1):101

Life Events and Rites of Passage, 48(2):201

Literary Research and the American Modernist Era: Strategies and Sources, 48(3):312

\section{M}

Managing Children's Services in the Public Library, 48(2):206

The Martin Luther King, Jr., Encyclopedia, 48(3):312-313

The Medical Library Association Essential Guide To Becoming an Expert Researcher, 48(3):316

The Medical Library Association Guide to Health Literacy, 48(3):316-317

Merchandising Made Simple: Using Standards and Dynamite Displays to Boost Circulation, 48(3):317

Military Communications: From Ancient Times to the 21st-Century, 48(1):96

\section{N}

Nations and Nationalism: A Global Historical Overview, 48(3):313

The New Encyclopedia of Unbelief, 48(1):96-97

The Old West: History and Heritage, 48(4):410-411

Opportunity for Leadership: Full and Informed Participation, 48(3):317-318

Organized Crime: From Trafficking to Terrorism, 48(4):411-412

Our New Public, A Changing Clientele: Bewildering Issues or New Challenges for Managing Libraries?, 48(1):101

\section{P}

A Picture Book Primer: Understanding and Using Picture Books, 48(4):416

\section{Q}

The Quality Library: A Guide to Staff Driven Improvement, Better Efficiency, and Happier Customers, 48(2):206

Queer America: A GLBT History of the 20th Century, 48(2):201-202

Questioning Library Neutrality: Essays from Progressive Librarian, 48(2):206207

\section{$\mathbf{R}$}

Reality Rules! A Guide to Teen Nonfiction Reading Interests, 48(3):318

Reference Sources for Small and MediumSized Libraries, 48(4):416

Renewing Professional Librarianship: A

INDEX TO VOLUME 48

Fundamental Rethinking, 48(3):318

Research-Based Readers' Advisory, 48(2):207

Rich and Poor in America: A Reference Handbook, 48(2):202

Rights of the Disabled, 48(4):412

Rock Band Name Origins: The Stories of 240 Groups and Performers, 48(2):202-203

\section{$\mathbf{S}$}

Scientific Thought: In Context, 48(4):412-413

South Asia: An Environmental History, 48(2):203

Story Behind the Protest Song: A Reference Guide to the 50 Songs That Changed the 20th Century, 48(4):413

Student Encyclopedia of African Literature, 48(3):313-314

Student's Encyclopedia of American Literary Characters, 48(3):314

\section{$\mathbf{T}$}

The Thanksgiving Book, 48(2):203-204 Transforming Library Service through Information Commons: Case Studies for the Digital Age, 48(4):416-417

Treaties With American Indians: An Encyclopedia of Rights, Conflicts, and Sovereignty, 48(1):97-98

\section{U}

The Underground Railroad: An Encyclopedia of People, Places, and Operations, 48(1):98

User-Centered Library Websites: Usability Evaluation Methods, 48(3):318-319

U-X-L Encyclopedia of U.S. History, 48(4):413-414

\section{W}

Web Accessibility: Practical Advice for the Library and Information Professional, 48(4):417

What Every Librarian Should Know about Electronic Privacy, 48(2):207-208

Women, Science and Myth: Gender Beliefs from Antiquity to the Present, 48(3):314-315

Women Adventurers, 1750-1900, 48(1):98-99

Women in American Musical Theater, 48(2):204

Women in the American Civil War, 48(1):99-100

Women in the American West, 48(2):204205

World and Its Peoples: The Americas, 48(4):414 